\title{
A Canção do Exílio a Dezesseis Mãos
}

Apresentada em Fortaleza, Ceard, durante o VI Encontro de Tradutores.

\author{
Minha terra tem palmeiras, \\ Onde canta o Sabiá; \\ As aves que aqui gorgeiam, \\ Nāo gorgeiam como lá. \\ Nosso céu tem mais estrelas, \\ Nossas várzeas têm mais flores, \\ Nossos bosques têm mais vida, \\ Nossa vida mais amores. \\ Em cismar, sozinho, à noite, \\ Mais prazer encontro eu lá; \\ Minha terra tem palmeiras, \\ Onde canta o Sabiá.
}

Minha terra tem primores, Que tais nāo encontro eu cá, Em cismar - sozinho, à noite Mais prazer encontro eu lá; Minha terra tem palmeiras, Onde canta o Sabiá.

Não permita Deus que eu morra,

Sem que eu volte para lá;

Sem que desfrute os primores

Que não encontro por cá;

Sem qu'inda aviste as palmeiras,

Onde canta o Sabiá

Gonçalves Dias, em Poesias Americanas da obra Poesias Completas Vol. II Zélio Valverde, Rio de Janeiro, p. 77-78 


\section{Zarubiéinaia Piésnia}

$\checkmark$ maiei ródinie rastut palmi

Gdié paiót ptítsa sabiá

Zdiés ptítsi paiút

No nie tak kak u meniá.

V náchiem niébe bólchie sviózd

A v dalínakh palnó tsvietóv

$\checkmark$ liesákh stólhka jízni

Chto v náchiei jízni tólka liubóv.

Adín, nótchiu dúmaiu

Schástia naidú tólhka tám;

$\checkmark$ maiei ródine rastút pálmi

Gdié paiót ptítsa sabiá.

$\checkmark$ maiéi ródine vció priekrásna

Zdiés iá ták nie naidú

Adín, nótchiu dúmaiu

Schástia naidú tólka tám;

$\checkmark$ maiei ródinie rastút pálmi

Gdié paiót ptítsa sabiá.

Dai vot iá nie umrú

Nie viernústsia tudá

Nie uvídia krassatú

Chto zdiés iá ne naidú

Nie uvídia eti pálmi

Gdié paiót ptítsa sabiá.

Tradução para o russo de Victoria Claire Weischtordt. 


\section{Зарубежны Песня}

В моей родине растут пальмы

Где поет птида сабил

Здесь птиды поют

Но не таx $\operatorname{xax}$ у менк.

В нашем небе больше свезд

A в далинах полно дветов

В десах стольо жизньи

Что в жашей хизньи тольхо любовь.

Один, ночью думаю

Счастье каиду тольхо там;

В моен родине растут пальмы

Где поет птица сабия.

В моей роднне все прехрасно

Здесь $х \operatorname{rax}$ не найду

Однн, ночью думаю

Счастье наиду только там

В моен родине растут пальмы

Где поет птича сабик.

$$
\begin{aligned}
& \text { Дай вот я не умру } \\
& \text { Не вернусша туда } \\
& \text { Не увидья красату }
\end{aligned}
$$

Что здесь $х$ не наиду

Не увидк эти пальмы

Где поет птича сабик.

Tradução para o russo de Victoria Claire Weischtordt. 


\section{Song of Exile}

My land has such palm trees

Where sings the sabiá.

The birds, which here sing,

Do not sing as they do there.

Our sky has more stars, our fields have more flowers, Our woods have more life,

Our life has more loves.

When at night, alone, I dream,

More pleasure find I there;

My land has such palm trees

Where sings the sabiá.

My land has such beauties

Which here cannot be found.

When at night, alone, I dream,

More pleasure find I there;

My land has such palm trees

Where sings the sabiá.

O God, let me not die, Before I go back there,

Before I enjoy the beauty

Which here cannot be found,

Before I see the palm trees

Where sings the sabiá.

Traduçāo para o inglês de John Milton. 


\section{Chanson d'Exil}

Mon pays a des palmiers,

Où chante le Sabiá;

Les oiseaux, qui ici trillent,

$\mathrm{Ne}$ le font comme là-bas.

Notre ciel a plus d'étoiles, Nos prairies ont plus de fleurs,

Nos forêts ont plus de vie,

Et notre vie plus d'amours.

Ô que songer, seul, le soir, M'était bien plus doux là-bas;

Mon pays a des palmiers,

Où chante le Sabiá.

Oui ma terre a des beautés, Qu'en ces terres il n'y a pas;

Ô que songer, seul, le soir,

M'était bien plus doux là-bas;

Mon pays a des palmiers,

Où chante le Sabiá.

Plaise à Dieu que je ne meure, Sans que ma terre ne revoie;

Sans jouir de ses beautés Qu'en ces terres il n'y a pas;

Sans voir encore les palmiers,

Où chante le Sabiá.

Tradução para o francês de Alain Mouzat, publicada em Economie et Culfure, junho de 1993 


\section{Lied aus der Verbannung}

Meiner Heimat Schmuck sind Palmen,

Wo im Hain die Drossel singt -

Schöner singt, als alle Vögel, lhre Stimme hier erklingt.

Heller funkeln uns're Sterne, Blumiger ist uns're Flur, Reicher unser Wald an Leben Und an Liebe die Natur.

Glücklich bin ich, wenn in stiller Nacht mein Geist ins Weite dringt Meiner Heimat Schmuck sind Palmen, Wo im Hain die Drossel singt.

Kann die Heimat mir ersetzen, Was das fremde Land mir bringt? Glücklich bin ich, wenn in stiller Nacht mein Geist ins Weite dringt Meiner Heimat Schmuck siñd Palmen,

Wo im Hain die Drossel singt.

Lass, Herr, noch den Tag mich schauen, Der mich in die Heimat bringt, In die Heimat, deren Zauber In des Herzens Tiefe dringt! Lass mich schau'n das Land der Palmen, Wo im Hain die Drossel singt!

Tradução para o alemão de Rodolfo Damm (Dresden 1858 - Blumenau 1915) 


\section{Eksilkvadet}

Mitt fedreland har palmtrær

Som bærer trostens sang.

Og fuglene som synger her

Synger ei som i mitt fjerne land.

Flere stjerner krysser vårt himmelhvelv;

Våre jorder av flere blomster bedekkes.

Det er mer liv å finne i våre skoger;

Mer elskov i våre liv kan leves.

Når jeg svermer alene, om natten

Søker jeg hen til mitt fjerne land.

Mitt fedreland har palmtrær

Som bærer trostens sang.

Mitt fedreland har øyenslyst

Som jeg ei her finne kan;

Nar jeg svermer, alene, om natten

Søker jeg hen til mitt fjerne land.

Mitt fedreland har palmtrær

Som bærer trostens sang.

M\& Gud forby at jeg dør

Før jeg vender att til mitt land;

Før jeg får nyde de øyenslyst

Jeg ei her finne kan;

Før jeg atter en gang får se de palmtrær

Som bærer trostens sang.

Tradução para o norueguês de Francis Aubert. 


\section{Shir ha Galut}

Beartsi dkalim, dkalim

Bahem shar hasabia

Tsiporim she can sharot

Lo iashiru cmo sham

\section{Beshmeimeinu cohavim merubim ioter \\ Beamakeinu ioter prahim \\ Beiaaroteinu ioter haiim \\ Behaiieinu ahavot rabot ioter}

Behirhuri levad balaila

loter oneg motse ani sham

Beartsi dkalim, dkalim

Bahem shar hasabia

Leartsi iesh hen

Oto eineini motse can

Behirhuri levad balaila

loter oneg motse ani sham

Beartsi dkalim, dkalim

Bahem shar hasabia

Lo iten hael moti

Mibli she ashuv lesham

She lo ezke lehol hahen

She eineni motse can

Mibli she ashkif al hadkalim

Bahem shar hasabia

Tradução para o hebraico de Renee Ben Israel 


\section{בארצי דקלים, דקלים}

בהם שר הַסָּבְּיָה

צפורים שכאן שרות שפירות

לא ישירו כמו שם שרות

בשממינו כוכבים מרובים יותר

בעמקינו יותר פרחים כים מיובים

ביערותינו יותר חיים פרחים

בחיינו אהבות רבות יותר

בהרהורי לבד בלילה

יותר עונג מוצא אני שם

בארצי דקלים, דקלים

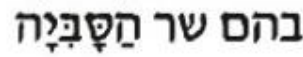

לארצי יש חן

אותו אינני מוצא כאן

בהרהורי לבד בלילה מוצה

יותר עונג מוצא אני שם לביל

בארצי דקלים, דקלים

בהם שר הַסְּבְּיָה

לא ייתן האל מותי

מבלי שאשוב לשם מית

שלא אזכה לכל החובן

שאינני מוצא כאן של של

מבלי שאשקיף על הדקלים

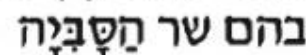

Tradução para o hebraico de Renee Ben Israel 


\section{Cântarea Exilului}

Tara mea are palmieri Unde cântă Sabiá

Păsări ciripesc pe aici,

Dar nu precum pe coleà.

Cerul nostru - multe stele! Câmpul nostru - multe flori! Codrii noștri - multă viată!

Viața noastră - mult amor!

Cugetând singur din noapte, Plăcerea o întâlnesc coleà, Tara mea are palmieri Unde cântă Sabiá.

Tara mea oferă daruri Ce aici nu le voi vedeà; Cugetând singur din noapte, Plăcerea o întâlnesc coleà, Tara mea are palmieri Unde cântă Sabiá.

Nu mă lase Zeii să mor

Fără să mă întorc coleà; Fără să guste plăcerile Ce aici nu le voi vedeà; Fără să mai văd palmierii Unde cântă Sabiá

Tradução para o romeno de Luciano Maia 
Cadernos de Literatura em Tradução ñ. 1, p. 7-17

\section{Canzone dell'esilio}

II mio paese ha palmeti,

Dove canta il Sabiá;

Gli ucelli che qui gorgheggian,

Non gorgheggian come là.

II nostro cielo ha più stelle,

I nostri campi più fiori,

I nostri boschi più vita,

La nostra vita più amori.

A sognar, solo, la notte,

Più piacere io trovo là;

II mio paese ha palmeti,

Dove canta il Sabiá.

II mio paese ha incanti, Che io non ritrovo qua;

A sognar, solo, la notte,

Più piacere io trovo là;

II mio paese ha palmeti,

Dove canta il Sabiá.

Non permetta Dio ch'io muoia

Senza ch'io ritorni là;

Senza che goda gl'incanti

Che io non ritrovo qua;

E ancor riveda i palmeti,

Dove canta il Sabiá.

Traduçõo para o italiano de Marcella Mortara 